\title{
The Effects of L1 Translation vs. Paraphrasing the Literary Texts on Female and Male Students Reading Comprehension
}

\author{
Maryam Pakzadian \\ Department of English, University of Isfahan, Isfahan, Iran \\ Email: maryam.pakzadian2011@gmail.com \\ Hossein Barati \\ Department of English, University of Isfahan, Isfahan, Iran \\ Email: h.barati@gmail.com \\ Ahmad Moinzadeh \\ Department of English, University of Isfahan, Isfahan, Iran \\ Email: moin@fgn.ui.ac.ir
}

\begin{abstract}
During the last decades, the role of mother tongue in language teaching has been the subject of a host of research studies (e.g., Block, 1986; Kern, 1994; Jimenez, Garcia, and Pearson, 1996; Upton, 1997); however, quite rarely have researchers addressed such issues as comparing the use of mother tongue and other teaching techniques like paraphrasing and translation effects on teaching specific texts in literary courses. This study aimed to explore whether paraphrases vs. translations of English poems make any significant difference in EFL students' level of comprehending literary texts. It also aims to examine whether paraphrases or translations of literary text at undergraduate level affect significantly the performance of male and female students' comprehension of such texts. The data for this study were collected through two comprehension tests and a personal questionnaire from 40 English students who study at University of Isfahan. The data were analyzed descriptively and also inferentially. The overall findings of the study indicated that there was no significant difference between the comprehension of those who received Persian translation of the poems and those who dealt with the paraphrase of the same poems. However in the group, in which students received translation of the poems, the male participants significantly outperformed the female learners whereas in the group in which students received the paraphrase of poems, the female participants significantly outperformed the male learners. The findings of the present study would help teachers and teacher trainers to construct and implement $\mathrm{L} 1$ and paraphrase in literature classes more effectively.
\end{abstract}

Index Terms - translation, paraphrase, reading comprehension, literary translation

\section{INTRODUCTION}

English poetry has been taught in Iran for many years. The dominant method of teaching poetry during all these years has mostly been teachers lectured on the points that they thought would prepare the students for particular exams.

The main objective of teaching literature in the undergraduate departments of Iranian universities is to acquaint students with various literary genres, and consequently introducing them to the social, cultural, literary and intellectual backgrounds of other nations. Although instructors vary slightly in their treatment of literature, a common tendency can be traced out in their approaches. Adopting a traditional approach to teaching poetry, many instructors devote most of the valuable time of the class to "extrinsic" properties of literary texts imparting biographical, historical, aesthetic and philosophical information to the students. A large number of students will manage to pass the final exams by memorising the critical reviews of the poems. How many students brought up by this method will be the voluntary readers of poetry after they graduate from the college? Undoubtedly many of them will regard their literature classes as boring, monotonous and uninteresting.

Although the attitude of many instructors towards teaching poetry has changed considerably in the past years and even some ESP teachers believe that a well-chosen approach to the teaching of literature has some benefits for their students, there are very few teachers who advocate the inclusion of a new methodology to teaching poetry in their syllabus. Some instructors are ready to teach novels, short stories, plays and even essays, but very reluctant to teach poetry because they are well aware that with the old methods they cannot make poetry come alive for their students. Thus, if the methodology currently used in the poetry classes is not effective and successful, it is worthwhile experimenting with other methods and finding out whether they will yield significantly different result both on 
educational and the attitudinal levels. The researcher wants to investigate the role of translating and paraphrasing literary poems in comprehending them.

\section{CONCEPTUAL FRAMEWORK}

\section{A. L1 in EFL Classes}

The use of first language (L1) by second language (L2) readers to help them comprehend texts has been noted in many studies (e.g., Block, 1986; Kern, 1994; Jiménez, García, and Pearson, 1996; Upton, 1997).

While there are studies to understand further the role of L1 use in comprehending L2 texts (Cohen 1995; García, 2000) throughout decades of foreign language (L2) teaching, a recurring issue has been the role of the first language (L1) in the classroom. A long-term and wide-ranging debate persists regarding practical and theoretical questions about the significance of the L1's obvious influence on the L2 being learned.

Although many feel that the L1 should not be used in the classroom, other researchers, teachers, and learners do see a role for the L1 and support its use as a communication strategy and instructional tool (Fung, Wilkinson, and Moore 2003; Mukattash 2003; Sheen 2001; Tang 2002).

A special classroom use of the L1 is the translation of L2 texts into the L1, a procedure that has been neglected, possibly because of its association with the old Grammar Translation Method (Owen 2003).

However, current research reveals that today's translation activities have little to do with the previous method, which occurred in a non-interactive teacher-centered classroom with few activities aside from the translation of difficult, nonrelevant, and often boring texts (Bonyadi 2003; Owen 2003).

According to Vaezi and Mirzaei (2007) the idea of the effectiveness of using translation from L1 to L2 as a teaching technique to improve a group of Iranian EFL learners' linguistic accuracy was supported. Therefore, it can be concluded that translating form L1 to L2, using specific structures, can enhance learners' linguistic accuracy within the scope of those structures.

It also manifests that learners' mother tongue is not a useless element in second or foreign language learning. In other words, mother tongue, if used purposefully and systematically, can have a constructive role in teach Many teachers recognize that $\mathrm{L} 1$ in the classroom is a positive representation of inter-language. The data on inter-language and language transfer show that it is highly probable that L2 learners will always think most often in their L1, even at the advanced level (Mahmoud 2006).

Moreover, translation in L2 classroom offers a way to highlight similarities and differences between L1 and L2 forms. The translation is useful for L2 acquisition because, firstly, it uses authentic materials, secondly, it is interactive, thirdly, it is learner-centered, and finally it promotes learner autonomy (Mahmoud 2006).

Translation can also be used as a productive means to learn new L2 vocabulary. And translation can draw the teacher's attention to the words and structures that need to be practiced (Van Els et al. 1984).

For something different, Tuck (2003) proposes the use of L1 to L2 translation as a guided writing exercise for beginners, using process approach activities such as writing practice, dictionary work, and peer-correction opportunities.

There are a number of researches which either support or oppose the use of first language in a foreign language classroom. Some researchers have promoted the exclusive use of target language in monolingual foreign language classrooms. Particularly, the practitioners who support the strong version of communicative language teaching emphasize on learning to communicate through interaction in the target language and frown upon the use of the L1 in EFL classrooms.

Macdonald (1993, cited in Ustiinel and P. Seedhouse, 20o5) argues that switching to the L1 to explain what the teacher has said to learners is unnecessary and undermines the learning process. Thus, according to him, teaching entirely through the target language allows learners to experience unpredictability and to develop their own L2 system.

Translation is sometimes referred to as the fifth language skill alongside the other four basic skills (listening, speaking, reading, writing): "Translation holds a special importance at an intermediate and advanced level: in the advanced or final stage of language teaching, translation from L1 to L2 and L2 to L1 is recognized as the fifth skill and the most important social skill since it promotes communication and understanding between strangers" (Ross 2000).

Prodromou (2000) refers to the mother tongue as a 'skeleton in the closet', while Gabrielatos (2001) calls it a 'bone of contention'. Such views are but a mere reflection of the different methodological shifts in English Language Teaching, which have brought about new and different outlooks on the role of the mother tongue.

\section{B. Paraphrase for Comprehension}

One of the reasons paraphrasing for comprehension works so well is because it integrates all modes of communication--reading, writing, listening, and speaking--which leads to a deeper understanding of the text. The tie between reading and writing has long been established as an effective means of strengthening comprehension.

Vacca and Vacca (1999) stated, "Students who experience the integration of writing and reading are likely to learn more content, to understand it better, and to remember it longer" (p. 262).

Harvey and Goudvis (2007) contended that "opportunities for peer discussion and response build community and enhance understanding for all kids in the class" (p. 30). When introducing the concept of paraphrasing to students, it is important for teachers to first discuss the meaning. 
The voice of the original author is maintained in a good paraphrase. If the original text is written with passion, the paraphrase should also be passionate. If the text is humorous, the paraphrase should be, too. Other voices that might be identified in a text could include sarcasm, satire, persuasion, or melancholy. It is important for students to identify the author's voice before beginning the process of paraphrasing. This process helps students identify with the characters in their reading.

As Harris and Sipay (1990) observed, "Being able to restate another's thoughts in one's own language clearly and unambiguously is a crucial test of whether the thoughts were understood" (p. 537).

Paraphrasing is useful in the application of rules and procedures because it presents the information in a different and more simplified way. This helps clarify rules and procedures for learners. Learners can also demonstrate their understanding of rules and procedures by paraphrasing them. Paraphrasing can be used with other tactics such as Application Flowcharts and Application Frames by having the learners Paraphrase the information contained in these structures.

It is important to note that Paraphrasing is a difficult tactic for learners to use. Extensive practice and feedback may be necessary before the learners become comfortable Paraphrasing. In addition, when using Paraphrasing to present material to learners, it is only appropriate to Paraphrase if the original information is difficult to understand.

\section{Teaching Literature in EFL Classrooms}

Literature was initially the main source of input for teaching in language classes in the era of Grammar Translation Method but since then it has been dropped down the pedestal. In fact with the advent of structuralism and audio-lingual method, literature was downplayed and ergo discarded to the periphery (Collie \& Slater, 1987, p.2). The teaching of poetry to EFL students has always been a very demanding task. It is commonly assumed that English poetry is too difficult for foreign students to cope with and therefore it will be out of their reach. For almost two or three decades, literature, in general, and poetry in particular, which had played an essential role in foreign language teaching in many countries has been excluded from language classrooms.

Povey (1979), a vehement advocate of teaching poetry in EFL situations, believe that instructors of poetry are somehow responsible for causing the negative attitude of students towards verse: Ironically, often one of the most difficult things about teaching poetry to foreign students in handling the teacher's own deeply wrought unhappiness with verse, the result of experiences he or she has suffered (p. 164).

Arthur (1968) ascribes the aversion of students toward literature to ignoring the students' response and their private exchange with the literary text. "If literature is to become a successful part of an ESL programme, ways must be found to make literature both useful and enjoyable" (p. 200).

\section{THE PURPOSE OF THIS STUDY}

This study considers the following purposes:

1. To find out the effectiveness of using mother tongue translation in English literature classes.

2. To find out the effectiveness of using paraphrase in English literature classes.

3. To compare the achievement of students regarding their level of comprehension in case of translation and paraphrase.

\section{METHOD}

\section{A. Design}

The present research enjoys an empirical design which lets the researcher collect the data via observation, experience, etc. The rational for the empirical design of the study is the positivism epistemology which accommodates quantitative research.

The study intended to address the following research questions:

1-Do paraphrases or translations of English poems make any significant difference in EFL students' level of reading comprehension?

2-Do paraphrases or translations of text in literature courses at undergraduate level affect significantly the performance of male and female students' reading comprehension?

Based on the above research questions, the following hypotheses were formulated:

1-There is no significant difference in EFL students' level of reading comprehension when they are provided with Persian translation or paraphrase for the English poems.

2-There is no significant difference in male and female undergraduates' level of reading comprehension when they are provided with the Persian translations or paraphrases for the English poems.

\section{B. Participants}

Forty senior Iranian university students were invited to contribute to this study. They were 15 male and 25 female students of the English literature, studying at university of Isfahan, Iran. The participants were aged between 20 and 28 and the average age for the group was 23 . All the participants had passed the same number of literary courses prior to 
their participation in this study. The data obtained by a personal questionnaire (see 3.4.2) indicated that they had all passed their main courses of literature specifically the courses related to reading and understanding poetry. Students were randomly divided to two groups: A and B. There were twenty students in each group.

\section{Instruments}

In this research, I used two types of instruments: two tests and one questionnaire. The two tests of reading comprehension composed of 3 poems by William Blake (28 November 1757 - 12 August 1827).Each poem was followed by it's Persian translation in one test and by its paraphrase in another. Below the translation or paraphrase of the poem, there were 10 multiple choice items. Therefore each test included 30 items. The three poems were The Tiger, The Cradle Song and The Garden of Love. The translated and paraphrased texts were examined by experts in the field of English literature. The Persian texts used in this study were the published translations of the poems by Hooshang Rahnama in his book, An Island in the Moon (2007). These texts are available in the market. Before the participants began completing the tests, they were given a personal questionnaire on their sex, age, term of study, and the literature courses they had passed prior to their participation in the present study. This questionnaire included 5 questions and the researcher used it to gather data about participants' demographic information.

\section{Procedure}

The data collection phase of the present study was conducted in September 2011. Two different classes at the University of Isfahan contributed to this research. Prior to completing the tests, the participants were informed about the aims of the study and how they could contribute to the investigation. Further, before the participants began completing the tests they were given the personal questionnaire on their sex, age, term of the study and the literature courses they had passed. They were then the researcher randomly given test A and test B were asked to complete the tests in 30 minutes. While the test takers were completing the tests, the researcher answered their questions(if any) in their native language, Persian. The students were also asked to attach their questionnaires to their answer sheets when handing in their test materials. As for the scoring of the test, each correct answer was given a single point. All the correct answers added up to a total sum. The data were then analyzed using SPSS software version 16 for windows. The data were analyzed descriptively and inferentially. The inferential statistic used here was t-test.

\section{RESUlTS}

First research question:

1. Do paraphrasing and translating texts in literature courses at undergraduate level make any significant difference in adult EFL students reading comprehension?

TABLE 4.1.

DESCRIPTIVE STATISTICS IN GROUP A AND B IN SEPARATION

\begin{tabular}{|l|l|l|l|l|l|}
\hline Kurtosis & Skewness & Std.deviation & Mean & Number & score \\
\hline 15.60 & 3.76 & 1.23 & 23.15 & 20 & Group A \\
\hline-.182 & -.312 & 3.76 & 22.45 & 20 & Group B \\
\hline
\end{tabular}

In table 4.1 descriptive statistics; including mean, standard deviation, skuness and kurtosis were reported separately in group A and B. Now at this point the researcher uses independent samples test in order to compare mean score in group A with mean score in group B. Based on having null hypothesis, two tailed samples t-test is applied. Table 4.2 which is Spss output, shows sig.2tailed equals .810 for equal variances assumed. It is not significant $(\mathrm{p}<.05)$

TABLE 4.2

INDEPENDENT SAMPLES TEST

\begin{tabular}{|c|c|c|c|c|c|c|c|c|c|c|}
\hline & & \multicolumn{2}{|c|}{$\begin{array}{l}\text { Levene's Test for } \\
\text { Equality of Variances }\end{array}$} & \multicolumn{7}{|c|}{ t-test for Equality of Means } \\
\hline & & \multirow[b]{2}{*}{$\mathrm{F}$} & \multirow[b]{2}{*}{ Sig. } & \multirow[b]{2}{*}{$\mathrm{t}$} & \multirow[b]{2}{*}{ df } & \multirow{2}{*}{$\begin{array}{l}\text { Sig. (2- } \\
\text { tailed) }\end{array}$} & \multirow{2}{*}{$\begin{array}{l}\text { Mean } \\
\text { Difference }\end{array}$} & \multirow{2}{*}{$\begin{array}{l}\text { Std. Error } \\
\text { Difference }\end{array}$} & \multicolumn{2}{|c|}{$\begin{array}{l}\text { 95\% Confidence Interval of } \\
\text { the Difference }\end{array}$} \\
\hline & & & & & & & & & Lower & Upper \\
\hline \multirow{2}{*}{ score } & Equal variances assumed & 2.272 & .140 & .242 & 38 & .810 & .70000 & 2.88986 & -5.15022 & $6.55022 \mathrm{E} 0$ \\
\hline & Equal variances not assumed & & & .242 & 22.489 & .811 & .70000 & 2.88986 & -5.28567 & $6.68567 \mathrm{E} 0$ \\
\hline
\end{tabular}

As Table 4.4 indicates, the $t$-value estimated is not significant ( $p>.05)$. This means there is no statistically significant difference between groups $\mathrm{A}$ and $\mathrm{B}$ in comprehending the poems when they are provided with the translation or the paraphrase of them.

The second research question

2. Do paraphrases and translations of text in literature course at undergraduate level affect significantly the performance of male and female students' reading comprehension?

Table 4.3 reports the descriptive statistics including mean, standard deviation, skewness and kurtosis in group A for female and male participants in separation. 
TABLE 4.3

MEAN AND STANDARD DEVIATION IN GROUP A

\begin{tabular}{|c|c|c|c|c|c|}
\hline kurtosis & skewness & Std.deviation & mean & number & \\
\hline-.389 & .767 & 3.55 & 21.14 & 14 & Females \\
\hline 5.134 & 2.235 & 22.59 & 27.83 & $\overline{6}$ & Males \\
\hline
\end{tabular}

As you see in table 4.3, you can see the difference between mean score of female and male participants. Mean score of male participants is higher than mean score of female participants. After measuring mean score of female and male participants in group A, in order to compare these two mean scores to see whether this difference is significant or not the researcher uses independent samples test.

4.4.

INDEPENDENT SAMPLES TEST(GROUP A)

\begin{tabular}{|c|c|c|c|c|c|c|c|c|c|c|}
\hline & & \multicolumn{2}{|c|}{$\begin{array}{l}\text { Levene's Test for } \\
\text { Equality of Variances }\end{array}$} & \multicolumn{7}{|c|}{ t-test for Equality of Means } \\
\hline & & \multirow[b]{2}{*}{$\mathrm{F}$} & \multirow[b]{2}{*}{ Sig. } & \multirow[b]{2}{*}{$\mathrm{t}$} & \multirow[b]{2}{*}{ df } & \multirow{2}{*}{$\begin{array}{l}\text { Sig. (2- } \\
\text { tailed) }\end{array}$} & \multirow{2}{*}{$\begin{array}{l}\text { Mean } \\
\text { Difference }\end{array}$} & \multirow{2}{*}{$\begin{array}{l}\text { Std. Error } \\
\text { Difference }\end{array}$} & \multicolumn{2}{|c|}{$\begin{array}{l}\text { 95\% Confidence Interval of the } \\
\text { Difference }\end{array}$} \\
\hline & & & & & & & & & Lower & Upper \\
\hline score & Equal variances assumed & 9.149 & .007 & 1.116 & 18 & .279 & 6.69048 & 5.99443 & -5.90335 & 19.28430 \\
\hline & $\begin{array}{l}\text { Equal variances not } \\
\text { assumed }\end{array}$ & & & .721 & & .502 & 6.69048 & 9.27329 & -16.99914 & 30.38009 \\
\hline
\end{tabular}

As Table 4.4 indicates, the t-value estimated significant $(\mathrm{p}<.05)$. This means there is a statistically significant difference between females and males in group A in comprehending the poems when they are provided with th the translation of them. Male participants outperformed in comprehending the poems when they received translation of poems in group A.

Table 4.5 reports the descriptive statistics, including mean, standard deviation, skewness and kurtosis in group B between male and female participants in separation. You can see mean score of females is higher than mean score of males in group A.

TABLE4.5

MEAN AND STANDARD DEVIATION IN GROUP B

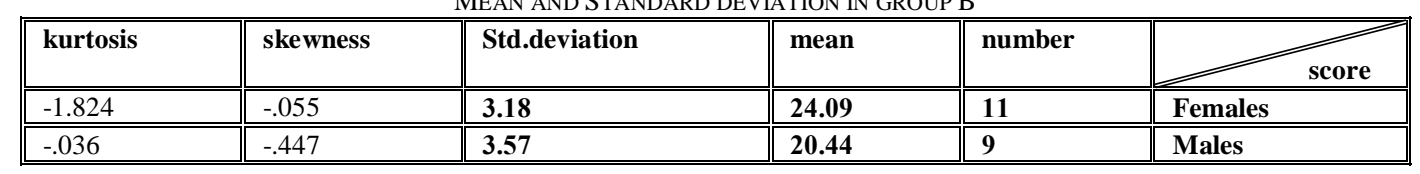

In table 4.5 we saw there was a difference between mean score of females and males in group B, and mean score of girls was higher. Now the researcher uses independent samples test to compare these two mean scores.

4.6.

INDEPENDENT SAMPLES TEST(GROUP B)

\begin{tabular}{|c|c|c|c|c|c|c|c|c|c|c|}
\hline & & \multicolumn{2}{|c|}{$\begin{array}{l}\text { Levene's Test for } \\
\text { Equality of Variances }\end{array}$} & \multicolumn{7}{|c|}{ t-test for Equality of Means } \\
\hline & & \multirow[b]{2}{*}{$\mathrm{F}$} & \multirow[b]{2}{*}{ Sig. } & \multirow[b]{2}{*}{$\mathrm{t}$} & \multirow[b]{2}{*}{ df } & \multirow{2}{*}{$\begin{array}{l}\text { Sig. (2- } \\
\text { tailed) }\end{array}$} & \multirow{2}{*}{$\begin{array}{l}\text { Mean } \\
\text { Difference }\end{array}$} & \multirow{2}{*}{$\begin{array}{l}\text { Std. Error } \\
\text { Difference }\end{array}$} & \multicolumn{2}{|c|}{$\begin{array}{l}95 \% \text { Confidence Interval of } \\
\text { the Difference }\end{array}$} \\
\hline & & & & & & & & & Lower & Upper \\
\hline score & $\begin{array}{l}\text { Equal variances assumed } \\
\text { Equal variances not } \\
\text { assumed }\end{array}$ & .061 & .808 & $\begin{array}{l}-2.415 \\
-2.385\end{array}$ & $\begin{array}{l}18 \\
16.251\end{array}$ & $\begin{array}{l}.027 \\
.030\end{array}$ & $\begin{array}{l}-3.64646 \\
-3.64646\end{array}$ & $\begin{array}{l}1.50990 \\
1.52876\end{array}$ & $\begin{array}{l}-6.81866 \\
-6.88324\end{array}$ & $\begin{array}{l}-.47427 \\
-.40969\end{array}$ \\
\hline
\end{tabular}

As Table 4.6 indicates, the $\mathrm{t}$-value estimated is significant $(\mathrm{p}<.05)$. This means there is statistically significant difference between females and males in group B in comprehending the poems when they are provided with the paraphrase of them. So females out performed in comprehending the poems when they received paraphrase of the poems in group B.

\section{RESEARCH HYPOTHESIS AND DISCUSSION}

H1. There is no significant difference in EFL students' level of reading comprehension when they are provided with Persian translation or paraphrase for the English poems.

In order to examine this null hypothesis, first Mean and Standard deviation were measured in both groups. Results show mean score of 23.15 for group A , and 22.45 for group B (see Table 4.1). The results show there is not any 
significant statistical difference between mean in group A and B. Then two tailed independent samples test was applied on the collected data. The results at this point indicates, the t-value estimated is not significant ( $\mathrm{p}>.05)$. This means there is no statistically significant difference between groups A and B in comprehending the poems when they are provided with the translation or the paraphrase of them (see Table 4.2). So based on the results the first null hypothesis cannot be rejected.

H2: There is no significant difference in male and female undergraduates' level of reading comprehension when they are provided with the Persian translations or paraphrases for the English poems.

To address the above hypothesis Mean and Standard deviation of female and male participants separately were estimated. Results show mean score of 22.44 for females and 23.4 for males. Results show there is not any significant statistical difference in mean of male and female students' scores. But when the results were analyzed separately in groups, it shows mean score for boys is higher than mean score for girls in group A (see Table 4.4).

And we can say boys outperformed in group A, in which they received Persian translation of English poems. In group B in which subjects received paraphrases of English poems, results it is understood that mean score of the girls who receive paraphrase is higher than boys and this is significantly important. So comprehension level for girls in comparison to boys is higher in group B (see Table 4.6). So based on the results the second null hypothesis was rejected.

The results of present study have nothing in contrast with what Kern came in to in his results. In a study investigating the language of thought used in comprehending L2 texts among fifty-one students of French, (Kern, 1994) found that use of L1 translation during L2 reading played "an important and multidimensional role in the L2 reading comprehension processes" of the students. However, Kern also pointed out that translation can be unproductive when it is done in a word-by-word fashion without integration of meaning. In general, (Kern ,1994) suggested that teachers and L2 learners should not view translation as "an undesirable habit to be discouraged at all costs but, rather, an important developmental aspect of L2 comprehension processes."

Although the results of present study do not show any significant difference in terms of reading comprehension between subjects in group A and subjects in group B, we can see mean score in group A is higher than mean score in group B. And maybe this is due to limitations of this study. With larger number of participants, and more careful sampling maybe we could reach the same results. But as the results due to second null hypothesis showed boys outperformed in their reading comprehension when received L1 translation of English poems. So for females translation played a positive role in comprehending the texts and this verifies what kern said about positive role of using L1 in teaching L2.

And even the results of present study do not reject the results of setiawati's article. Aprilia Setiawati (2011) in her article named; "The Effectiveness of Paraphrasing to Improve Students' Reading Comprehension Skills of Hortatory Exposition Text" used a pre-experimental design by applying pre-test post-test design and cluster random sampling. The experimental group had four meetings. The first meeting was for giving pre-test. The second and third meetings were for treatments by using paraphrasing in teaching reading comprehension of hortatory exposition text. For the last meeting, the post-test was given to the students to know their achievement. The result of the pre-test showed that the average score of pre-test was 70.7. Whereas, the averages score of post-test was 75.325. From the data, the result of post-test in comprehending hortatory exposition text was better than the result of pre-test. So, there was an improvement of students' ability in comprehending hortatory exposition text through paraphrasing. In order to find out the significance of the increase between pre-test and post-test, t-test was applied. After having the test of significance, the $t-$ value (2.678) was higher than t-table (2.02). From the result, it could be concluded that using paraphrasing can effectively improve the students' reading comprehension skills of hortatory exposition text.

The results of present study never ignore the positive role of using paraphrase in EFL classroom, and as Setiawati concluded in her article it's a useful way to comprehend L2 texts better. If the present study enjoyed a control group we could see the role of paraphrase on student's comprehension away from comparing it with translation in to L1. And this could be due to one of other limitations of this study which is having no group as control group. But as results due to second null hypothesis show male participants outperformed in their reading comprehension when they received paraphrase of the texts.

Seraj (2010) in his MA thesis investigated the role of L1 in learning new vocabulary. To attain above goal, he chose six passages and 3 groups of learners. He provided the definitions of new words in English for one group; in second group he provided mother tongue definitions (Persian) on new words (these definitions succeeded the words immediately in brackets). And in third group no definition was provided. He compared the results of three groups in order to find which group did better in learning of new words. After analyzing the data, using ANOVA, the results showed that there was no significant difference between 3 groups. The results of the aforementioned study are similar to the results of present study in which no significant difference between groups is observed.

Seraj tried to compare 3 groups in terms of their reading comprehension and new vocabulary learning. Although the results did not show any significant difference between 3 groups in terms of reading comprehension, Seraj reported that when students received Persian meaning of new vocabulary in the texts, according to the results of retention test, later they remembered them better. Seraj's study enjoyed a control group which let the researcher investigate positive role of L1 in learning new vocabulary separately and positive role of giving English definition of new words in another side. 


\section{LIMITATIONS OF THE STUDY}

This study faced a number of limitations which will be discussed briefly in the following lines.

1. Although before completing the tests the participants were given a personal questionnaire on their sex, age, term of study and literature courses they had passed prior to their participation in the present study, we do not have any information about students' prior studies in literature beside their university courses. Some students even have considerable amount of knowledge in English or Persian literature which affects their performance on the test.

2. Second research question aims to investigate whether paraphrases or translations of text in literature courses at undergraduate level affect significantly the performance of male and female students' reading comprehension. As soon as these days number of female students is more than male students in universities of Iran and especially majors like English, in the present study frequency of female participants are more than male participants. With larger number of participants including the same number of boys and girls maybe the results would change.

3. The test includes 3 English poems and their paraphrases or translations followed with 30 comprehension tests. And this may cause fatigue on the side of test takers and they do not pay enough attention necessary for completing the test and this will affect the results.

4. In the present study effectiveness of using translation and paraphrase of English poems were compared. If this study enjoyed having a control group, it was possible to investigate effectiveness of each of these techniques in comprehending the text separately.

5. The present study did not say anything about subject's attitudes toward the two techniques under investigation. It could tell how students feel about each of these techniques and their effectiveness.

\section{CONCLUDING REMARKS}

In this paper the researcher investigated whether paraphrases or translations of English poems make any significant difference in EFL students' level of reading comprehension and whether paraphrases or translations of text in literature courses at undergraduate level affect significantly the performance of male and female students' reading comprehension.

The results showed there was not any significant statistical difference between mean in group A and B. Then two tailed independent samples test was applied on the collected data. The results at this point indicates, the $\mathrm{t}$-value estimated is not significant $(\mathrm{p}<.05)$. This means there is no statistically significant difference between groups A and B in comprehending the poems when they are provided with the translation or the paraphrase of them. And we can say boys outperformed in group A, in which they received Persian translation of English poems. In group B in which subjects received paraphrases of English poems, results it is understood that mean score of the girls who receive paraphrase is higher than boys and this is significantly important. So comprehension level for girls in comparison to boys is higher in group B.

\section{REFERENCES}

[1] Arthur, B. (1968). Reading Literature and Learning a Second Language. Language Learning, 18/4 and 4.

[2] Block, E. (1986). The comprehension strategies of second language readers. TESOL Quarterly, 20, 463-494.

[3] Bonyadi, A. (2003). Translation: Back from Siberia. Translation Journal 7 (3). http://accurapid.com/journal/25edu.htm. Last updated on: 12/20/2010 16:41:46

[4] Cohen, A. D. (1995). In which language do/should multilinguals think? Language, Culture, and Curriculum, 8, 99-113.

[5] Collie, J., \& Slater, S. (1987). Literature in the Language Classroom. Cambridge, UK: Cambridge University Press.

[6] Fung, I. Y. Y., I. A. G. Wilkinson, and D. W. Moore. (2003). L1-assisted reciprocal teaching to improve ESL students' comprehension of English expository text. Learning and Instruction 13 (1): 1-31.

[7] García, G. E. (2000). Bilingual children's reading. In M. Kamil, P. Mosenthal, D. Pearson, \& R. Barr (Eds.), Handbook of reading research Volume III (pp.163-179). Hillsdale, NJ: Lawrence Erlbaum Associates.

[8] Harris, A.J., \& Sipay, E.R. (1990). How to increase reading ability: A guide to developmental and remedial methods (9th ed.). White Plains, NY: Longman.

[9] Harvey, S. \& Goudvis, A. (2007). Strategies that work: Teaching comprehension for understanding and engagement. Portland, ME: Stenhouse Publishers.

[10] Kern, R. G. (1994). The role of mental translation in second language reading. Studies in Second Language Acquisition, 16, 441-461.

[11] Macdonald, c. (1993). Using the Target Language'. Cheltenhman: Mary Glasgow.

[12] Mahmoud A. (2006). Translation and Foreign Language Reading Comprehension: A Neglected Didactic Procedure. English Teaching Forum, 44 (4), p. 28-33.

[13] Owen, D. (2003). Where's the treason in translation? Humanising Language Teaching 5 (1). Didactic Procedure. English Teaching Forum, 44 (4), p. 28-33.

[14] Povey, J. F. (1979). "The Teaching of Literature in Advanced ESL Classes." In L. McIntosh \& M. Celce-Murcia (Eds.), Teaching English as a Second or Foreign Language (pp. 162-186). Rowley, MA: Newbury Houge.

[15] Prodromou L. (2002). 'The Role of the Mother Tongue in the Classroom' IATEFL ISSUES April-May pp.6-8

[16] Rahnama, H. (2007). ' The translation of An Island in the Moon selected lyrics'. Tehran: Herms.

[17] Ross N. J. (2000). Interference and Intervention: Using Translation in the EFL Classroom. Modern English Teacher, No 9(3). p. $61-66$. 
[18] Upton, T. A. (1997). First and second language use in reading comprehension strategies of Japanese ESL students. TESL-EJ, 3(1), 22pp.

[19] Vacca, R., \& Vacca, J. (1999). Content area reading. New York: Longman.

[20] Vaezi, S., \& Mirzaei, M. (2007, September). The effect of using translation from L1 to L2 as a teaching technique on the improvement of EFL learners' linguistic accuracy - focus on form. Humanising LanguageTeaching, 9(5). Retrieved February 20, 2008 from http://www.hltmag.co.uk/Sep07/mart03.htm.

Maryam Pakzadian (First author) has a MA in ' Teaching English as a foreign Language' from University of Isfahan and she has got her BA in 'English Literature' from University of Isfahan. She has been involved in research in English Literature, Literary Translation, psycholinguistics, and Computer Assisted Language Learning. He has presented different lectures on Literary Translation, Teaching Translation and CALL.

Maryam is currently working on ' Persian Translation of William Blake's Songs of Innocence and Songs of Experience' and 'A New Approach to teaching Literature in Iranian Universities'.

Hossein Barati works in the English department, University of Isfahan, where he is assistant Professor of Applied Linguistics. He has a $\mathrm{PhD}$ in 'Language Testing' from University of Bristol and has been involved in research in language testing, programme evaluation, reading strategies, and classroom discourse. Before becoming a university lecturer in 1992, he worked as a language teacher at Ministry of Education, Isfahan, Iran. He has published in areas of language testing and assessment, and language programme evaluation. He is a member of a research project on Developing a new model of teaching to adult English non-majors at University of Isfahan, funded by University of Isfahan.

$\mathrm{He}$ has also co-authored some publications on DIF in Iranian National University Entrance Exam (INUEE), 2007; Linguistic constraints and language teaching, 2008; and Cultural differences in EFL performance on cloze tests, 2010. Further a text-book $A$ step forward in English for intermediate EFL learners is among his latest publications.

Hossein is currently working on 'New plans for Teaching English to Iranian adult non-majors', 'Teaching English to Iranian young learners, and 'The consequential validity of high stakes tests in the Iranian context'.

Ahmad Moinzadeh works in the English department, University of Isfahan, Where he is assistant Professor of Applied Linguistics. He has a PhD in 'Applied Linguistics' from University of Ottawa. 